\title{
Two decades of biomonitoring polar bear health in Greenland: a review
}

\author{
Christian Sonne ${ }^{1 *}$, Robert J Letcher ${ }^{2}$, Thea $\varnothing$ Bechshøft ${ }^{1}$, Frank F Rigét ${ }^{1}$, Derek CG Muir ${ }^{3}$, Pall S Leifsson ${ }^{4}$, \\ Erik W Born ${ }^{5}$, Lars Hyldstrup ${ }^{6}$, Niladri Basu ${ }^{7}$, Maja Kirkegaard ${ }^{8}$, Rune Dietz $^{1}$
}

From Environmental contaminants and animal health. The 26th Symposium of the Nordic Committee for Veterinary Scientific Cooperation (NKVet)

Helsinki, Finland. 6-7 October 2011

\section{Summary}

We present an overview of studies of anthropogenic pollutants in East Greenland polar bears over the period of 1999-2011. East Greenland polar bears are among the most polluted species, not just in the Arctic but globally, and represent an excellent biomonitoring species for levels and effects of global pollution in an apex predator.

Therefore, an international multidisciplinary team joined to monitor and assess the patterns and concentrations of contaminants and their potential negative impact on polar bears. The review showed that East Greenland polar bears are exposed to a mix of chlorinated, brominated and fluorinated organic compounds as well as mercury which are all known to have endocrine, immune and organ-system toxic properties. For example, the concentrations of PCBs (polychlorinated biphenyls) in blubber ranged approximately 800-21,000 ng/g Iw while mercury concentrations in liver and kidney ranged 0.1-50 $\mathrm{mg} / \mathrm{g} w \mathrm{w}$. Regarding health endpoints, bone density seemed to decrease as a function of time and $\mathrm{OHC}$ (organohalogen compound) concentrations and further T-score for adult males indicated risk for osteoporosis. .The size of sexual organs decreased with increasing $\mathrm{OHC}$ concentrations. In the lower brain stem, mercury-associated decreases in NMDA-receptor levels and DNAmethylation was found The present review indicated that age was one of the major drivers for liver and renal lesions, although contaminants and infectious diseases may also play a role. Lesions in thyroid glands were most likely a result of infectious and genetic factors and probably, together with endocrine disrupting chemical (EDCs), the reason for disturbances/fluctuations in blood plasma thyroid hormone concentrations. Except for bone density reductions and neurological measures, all findings were supported by case-control studies of Greenland sledge dogs exposed long-term orally to similar combinations of contaminant concentrations. The studies of sledge dogs also indicated that the mixture of contaminants and fatty acids in the blubber of prey similar to that of polar bears induces cellular as well as humoral immune toxic changes. These controlled studies using model species for polar bears indicate that the correlative findings between health endpoint and contaminants in polar bears could be a cause-and-effect relationship. Physiologically based pharmacokinetic (PBPK) modelling showed that the risk quotients were $\geq 1$ for $\Sigma P C B$, dieldrin and PFOS, which indicate an increased risk of prenatally reproductive pathology. In conclusion polar bears are susceptible to long-range transported chemicals that may have various adverse effects on multiple organ systems such as the reproductive and immune system.

\footnotetext{
* Correspondence: csh@dmu.dk

'Department of Bioscience, Faculty of Science and Technology, Aarhus

University, Frederiksborgvej 399, PO Box 358, DK-4000 Roskilde, Denmark

Full list of author information is available at the end of the article
} 


\section{Background}

The use of East Greenland polar bears (Ursus maritimus) as a biomonitoring key species for measuring exposure to $\mathrm{OHCs}$ (organohalogen compounds) and $\mathrm{Hg}$ (mercury) was initiated in Scoresby Sound in 1983 and is now the most comprehensive time trend studies of pollution on this species [1-7]. In addition, museum samples of skin and skulls collected since year 1892 have been included for $\mathrm{Hg}$ analysis and various patho-morphological and toxico-pathological density analyses [4,6-11].

The studies of adverse health effects of pollution were started in 1999 by the implementation of a biomonitoring health programme via AMAP (Arctic Monitoring and Assessment Programme) [12-14]. The reason for choosing polar bears, and for upgrading the research intensity, was because the East Greenland polar bear subpopulation is one of the most contaminated and that local Inuit people rely on this species as a food resource in addition to ringed seal (Phoca hispida) that plays a much greater role. Because polar bears reflect temporal trends and biological effects of contaminants they may also serve as a proxy for human health exposure and possible effects despite the fact that the physiology, metabolism, food and way of life of these two species differ fundamentally [e.g. [5,7,13-15]].

We present an overview of contaminant concentrations and potential adverse health effects from anthropogenic contaminants in polar bears during the period 1999-2010. The health effects include decrease in bone density, morphological changes in sexual organs, liver, kidney and thyroid glands, as well as potential neurological alterations and impacts on the immune and endocrine systems. Finally, some speculations about the synergistic effects of environmental stressors (e.g. decrease in sea ice) on polar bear health are presented.

\section{Levels of contaminants}

Chlorinated legacy contaminants (PCBs and OC pesticides), brominated flame retardants (PBDEs), perfluoroalkyl contaminants (PFCs) and Hg have been analyzed in brain, adipose tissue, liver, kidney, blood and hair samples from East Greenland polar bears. The range of contaminant concentrations used in relation to health endpoints during the period 1999-2002 are seen in Table 1. Concentrations increase in the order: $\mathrm{PBDEs}<\mathrm{PFCs}<\mathrm{PCBs}<\mathrm{Hg}$ and are in the concentration of having adverse health effects according to the international scientific literature $[13,14,16,17]$.

According to Dietz et al. [3-5,7] the concentrations of legacy chlorinated contaminants (PCBs and OC pesticides) have decreased and stabilized since 1990, while newer contaminants like PFCs and contemporary threats like $\mathrm{Hg}$ have increased. So, despite international regulations on all these groups of contaminants they persist and biomagnify in the environment, which results in a cocktail of toxic chemicals in the tissues of East Greenland polar bears.

\section{Skeletal system}

Analyses on the skeletal system have exclusively focused on skulls. The reasons for this are because Natural History Museums have archived these since 1892 and because skulls are relatively easily obtained in connection with the subsistence hunt.

We examined skull bone mineral density (BMD) in 139 bears in the period 1892-2009 and after controlling for age

Table 1 Concentrations of various contaminants [Mean (Min-Max, $n$ ] divided on tissues in East Greenland polar bears sampled 1999-2002. All data are in ng/g lw except for nPCBs, PCDDs and PCDFs (pg/g lw), PFCs (ng/g ww) and mercury ( $\mu \mathrm{g} / \mathrm{g} w w)$. Reworked from Sonne (2010)

\begin{tabular}{|c|c|c|c|c|c|}
\hline & Subcutaneous adipose tissue & Liver & Kidney & Brain & Blood \\
\hline Lipid-\% & 88 & 11 & - & 21 & 1.3 \\
\hline$\sum P C B$ & $6,543(897-20,407,92)$ & $28,409(12,836-67,664,20)$ & - & $148-2,186(20)$ & $538-15,692(20)$ \\
\hline $\mathrm{HCB}$ & $102(2.4-785,92)$ & $109(20)$ & - & $15(20)$ & $28(20)$ \\
\hline$\sum \mathrm{HCH}$ & $194(13-818,92)$ & $67(20)$ & - & $15(20)$ & $12-146(20)$ \\
\hline Dieldrin & $204(26-866,92)$ & $4,900(20)$ & - & - & - \\
\hline ¿Chlordane & $1,414(243-7,465,92)$ & $37,400(20)$ & - & $62(20)$ & $531(20)$ \\
\hline$\Sigma \mathrm{DDT}$ & $436(73-1,580,92)$ & $<0.1-476(20)$ & - & ND & $12-1,769(20)$ \\
\hline$\sum$ PBDE & $70(22-192,92)$ & $127-936(20)$ & - & $<0.5-36(20)$ & 38-146 (20) \\
\hline$\sum P F C$ & - & $1,056-8,010(29)$ & - & - & - \\
\hline$\sum n P C B$ & $241(125-442,5)$ & $124(114-148,5)$ & - & - & - \\
\hline$\sum P C D D$ & $10(7-12,5)$ & $20(8-38,5)$ & - & - & - \\
\hline$\sum \mathrm{PCDF}$ & $4(3-5,5)$ & $14(10-18,5)$ & - & - & - \\
\hline$\Sigma \mathrm{OH} / \mathrm{MeSO}_{2}-\mathrm{PCB}$ & $90-3134(20)$ & $1,882-18,018(20)$ & - & $66-352(20)$ & 29,692-226,154 (20) \\
\hline$\Sigma \mathrm{OH} / \mathrm{MeSO}_{2}-\mathrm{PBDE}$ & $<0.3-39(20)$ & $<0.5(20)$ & - & $<0.5(20)$ & $<0.5-1,060(20)$ \\
\hline$\sum \mathrm{MeSO}_{2}-\mathrm{p}_{1}, \mathrm{p}^{\prime}-\mathrm{DDE}$ & $9(20)$ & $482(20)$ & - & - & $769(20)$ \\
\hline Mercury & - & $11(1-36,59)$ & $14(1-50,57)$ & $0.4(0.1-0.9,82)$ & - \\
\hline
\end{tabular}


and sex we found that BMD decreased significantly over time in subadults (Figure 1) and adult males but not in adult females (data not shown) [18]. That a similar decrease was not found in adult females was likely due to the fact that they increase bone density prior to denning in order to avoid demineralisation. Otherwise, the low mechano-transduction and limited food intake and high calcium flux via foetal development and lactation transfer during denning theoretically should lead to clinical osteoporosis [19].

When correlating BMD with individual body burdens of OHCs in adipose tissue for individuals sampled during 1999-2002, significant inverse relationships were found in subadults (Figure 2) and adult males but not females [18]. Similar relationships were found for baculum BMD [20]. Furthermore, a calculation of T-score in males showed their risk of developing osteoporosis [14] as neuro-signalling may be influenced due to disruption of calcium homeostasis [21]. The exact pathways for these relationships are unknown; however, OHCs may disrupt brain and endocrine organ hormones as well as their transport proteins in polar bears as shown by multiple laboratory experiments $[13,14,18]$. During the study period 1892-2002 the pack sea ice in East Greenland has decreased [22]. Although undocumented, Sonne et al. [18] and Sonne [14] assumed that availability of polar bear prey (in East Greenland a variety of marine mammal prey other than ringed seals are available to polar bears) decreased simultaneous with the decrease in offshore sea ice and speculated whether this apparent decrease in sea ice may have led to increased energy expenditure and therefore indirectly served as a synergistic factor leading to reduced BMD.

\section{Reproductive organs}

Studying impacts from OHCs optimally includes investigation of the reproductive tract as adverse effects on this organ-system have a direct impact on the population size [14].

We studied gross morphology and histopathology in sexual organs from 55 male and 44 female polar bears sampled 1999-2002. When controlling for age, the analyses showed that size of testicles, baculum/penis, and ovaries/female reproductive tract decreased as a function of increasing $\mathrm{OHC}$ concentrations in adipose tissue (Figure 3) [20]. In addition to this we found enlarged clitoris (megaclitoris) in two adults but ascribed this to chronic inflammation rather than OHC exposure [14,23]. In adult males we found chronic orchitis, atrophy, and fibrosis independently of season, all of which could be partly ascribed to $\mathrm{OHC}$ exposure and infectious pathogens as shown by high-dose, short-term controlled laboratory experiments [20]. The pathways for these are suspected to be disruptions of brain and endocrine organ hormones as well as their transport proteins $[13,20]$. It is not possible to fully estimate the impact from these disruptions and pathological conditions, however, it is likely that semen quality and quantity could be influenced, which may have fatal consequences for fecundity and maintenance of population size.

\section{Liver, kidneys and thyroid glands}

Other key organs that are susceptible to endocrine disruption are the liver, kidneys, and various endocrine organs such and the thyroid glands and adrenals $[13,14]$. Liver $(\mathrm{n}=79)$, renal $(\mathrm{n}=75)$ and thyroid glands $(\mathrm{n}=20)$ were analyzed histologically in bears sampled 1999-2002. The evaluation, when not having a control group, is very difficult not least due to the effects from age and infectious diseases [14,24-28]. However, the various pathologies found in liver parenchyma and renal glomeruli, tubules and interstitium were similar to those found in controlled studies of $\mathrm{Hg}$ and $\mathrm{OHCs}$ in laboratory mammals and other OHC exposed wildlife [14,24-27]. The overall most

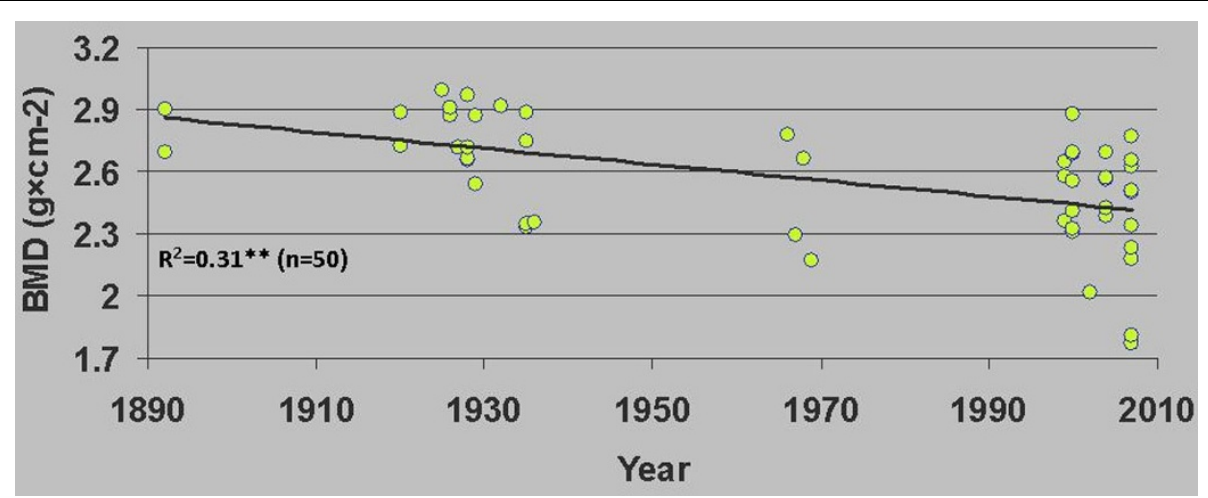

Figure 1 Bone mineral density $\left(\mathrm{g} \times \mathrm{cm}^{-2}\right)$ as a function of sampling year in subadult East Greenland polar bears sampled 1892-2002. $\mathrm{R}^{2}$ - and $\mathrm{p}$ values from a full multiple regression model controlling for age. ${ }^{* *}: p<0.01$. 


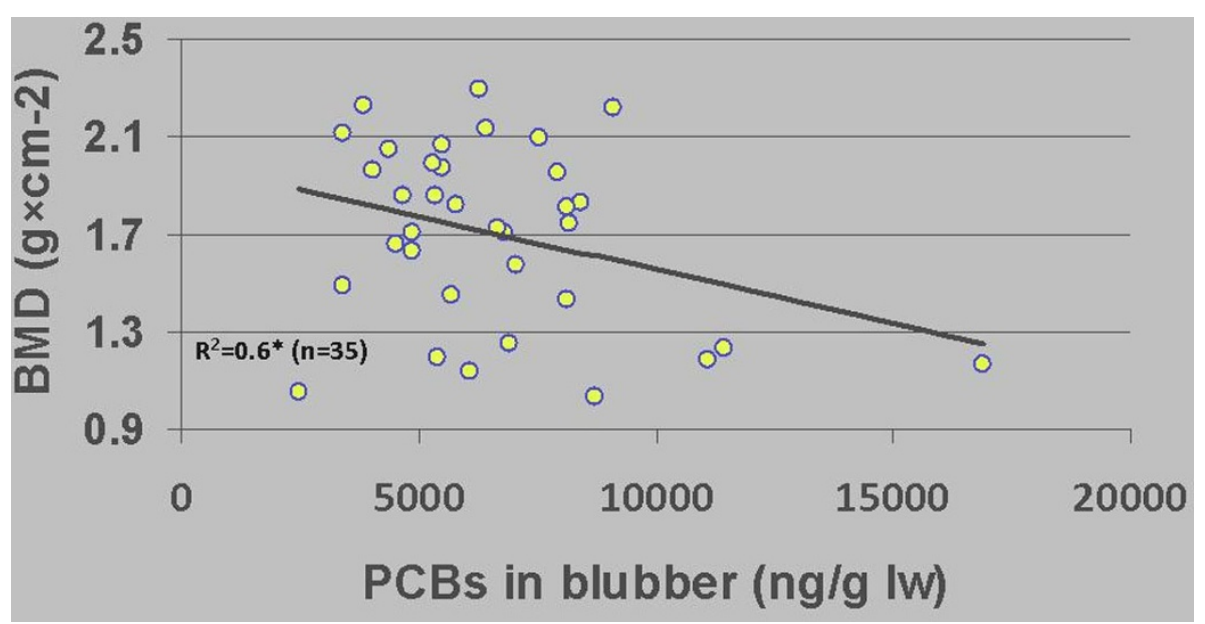

Figure 2 Bone mineral density $\left(\mathrm{g} \times \mathrm{cm}^{-2}\right)$ as a function of adipose tissue PCBs (ng/g lw) in subadult East Greenland polar bears sampled 19992002. $R^{2}$ - and $p$-values from a full multiple regression model controlling for age. $*: p<0.05$.

important parameters determining liver and renal pathology was age while also some statistical relationships were found between pathology and different chlorinated and brominated groups of contaminants as well as the liver and renal toxic $\mathrm{Hg}$ concentrations.

No histological lesions were found in any of the 50 adrenals examined while pathology was found in 8 out of 20 examined thyroid glands [28]. None of the thyroid gland lesions including c-cell hyperplasia, interstitial fibrosis, and nodular hyperplasia were associated with age or gender, so environmental factors such as energetic stress and autoimmunity/genetic could be co-factors as well as OHCs. Such lesions may interfere with the hypothalamic-pituitarythyroid (HPT) axis leading to endocrine disruptions having an impact on fecundity and foetal and neonatal development in East Greenland polar bears.

\section{Neuro-endocrine system}

During 1999-2002 we sampled the medulla oblongata from 82 specimens in order to analyze the concentrations of $\mathrm{Hg}$, a known neuro-toxicant. The analyses showed that the concentrations of $\mathrm{Hg}$ were relatively low compared to liver and kidney burdens, as well as other species, probably due to high demethylation capacity of the liver, formation of $\mathrm{Hg}$-selenium complexes, and fur as an efficient excretion route [29]. Despite the low Hg concentrations some inverse correlations of statistical significance were found. First, like in several other wildlife species [30,31], $\mathrm{Hg}$-associated decreases in the levels of NMDA receptor were found. The NMDA-receptor facilitates the neurotransmission of glutamate and is important for learning and $\mathrm{Hg}$ (Figure 4). Second, DNA methylation seemed to decrease with increasing $\mathrm{Hg}$ concentrations indicating potential epigenetic alterations in gene expression [32].

Villanger et al. [33] analyzed the circulating full blood concentrations of TT3 and TT4 in 62 East Greenland polar bears. The reason for analyzing thyroid hormones is the fact that this endocrine system is known to be extremely susceptible to EDC exposure including biotransformed metabolites such as OH-PCBs $[13,14,33]$. The analyses showed that various biological parameters such as age, size, and condition affected the circulating

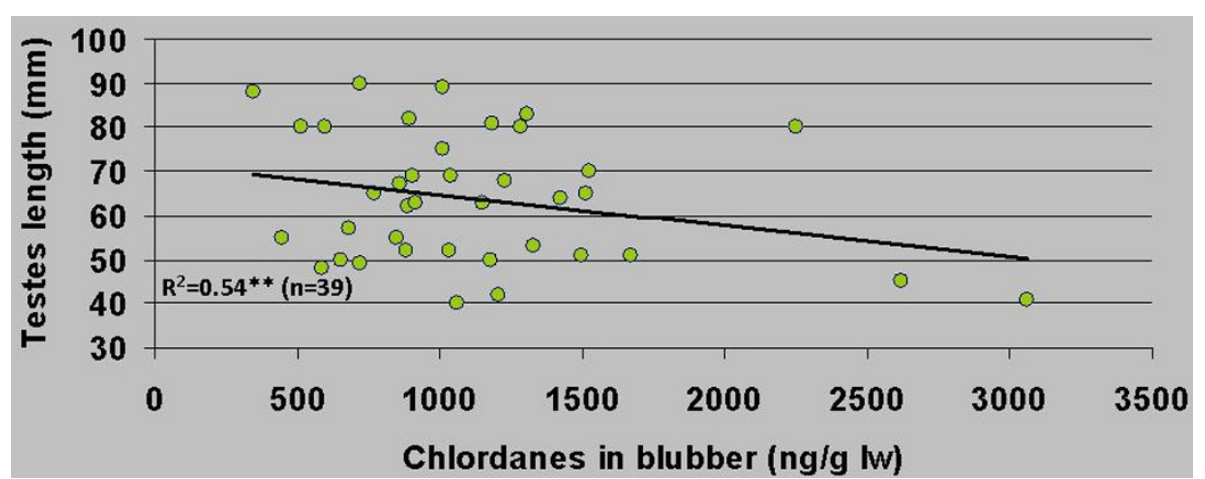

Figure 3 Testes length $(\mathrm{mm})$ as a function of adipose tissue chlordane concentrations ( $\mathrm{ng} / \mathrm{g} \mathrm{lw}$ ) in 39 East Greenland polar bears sampled 19992002. $R^{2}$ - and $p$-values from a full multiple regression model controlling for age. ${ }^{* *}: p<0.01$. 


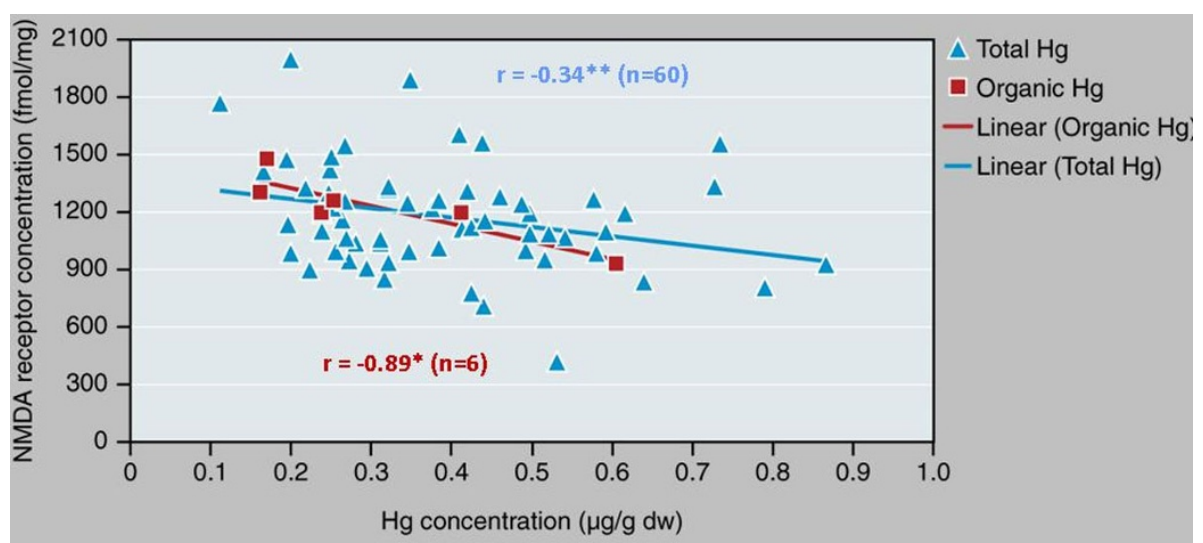

Figure 4 Correlations between NMDA-glutamate receptor levels and (A) Total Hg (blue) and (B) Organic Hg (MeHg; red) in the brain stem of 82 East Greenland polar bears sampled 1999-2002. Modified from Basu et al. [29]. *: $p<0.05$.

concentrations while different organochlorine contaminants and bromated flame retardants had negative as well as positive effects on the concentrations of both TT3 and TT4. The conclusions were that these correlations indicate biological effects on the HPT axis from EDC exposure, which is also supported by various in vivo studies of laboratory mammals as well as in vitro studies of polar bears $[13,14,33]$.

\section{Immune system}

Very little has been published on the East Greenland polar bear immune system $[13,14,34]$. However, investigations on Svalbard bears have indicated immune toxic effects at $\mathrm{OHC}$ exposure concentrations similar to the East Greenland polar bear's [13,14,35,36] and multiple studies in the laboratory and field show similar biological effects [13,14,37-39].

\section{Future challenges}

As shown above, contaminant exposure is suggested to have potential health effects on various organ-systems in East Greenland polar bears. However, contaminants are not the only environmental stressor in East Greenland (Figure 5). Also global warming leading to decreased

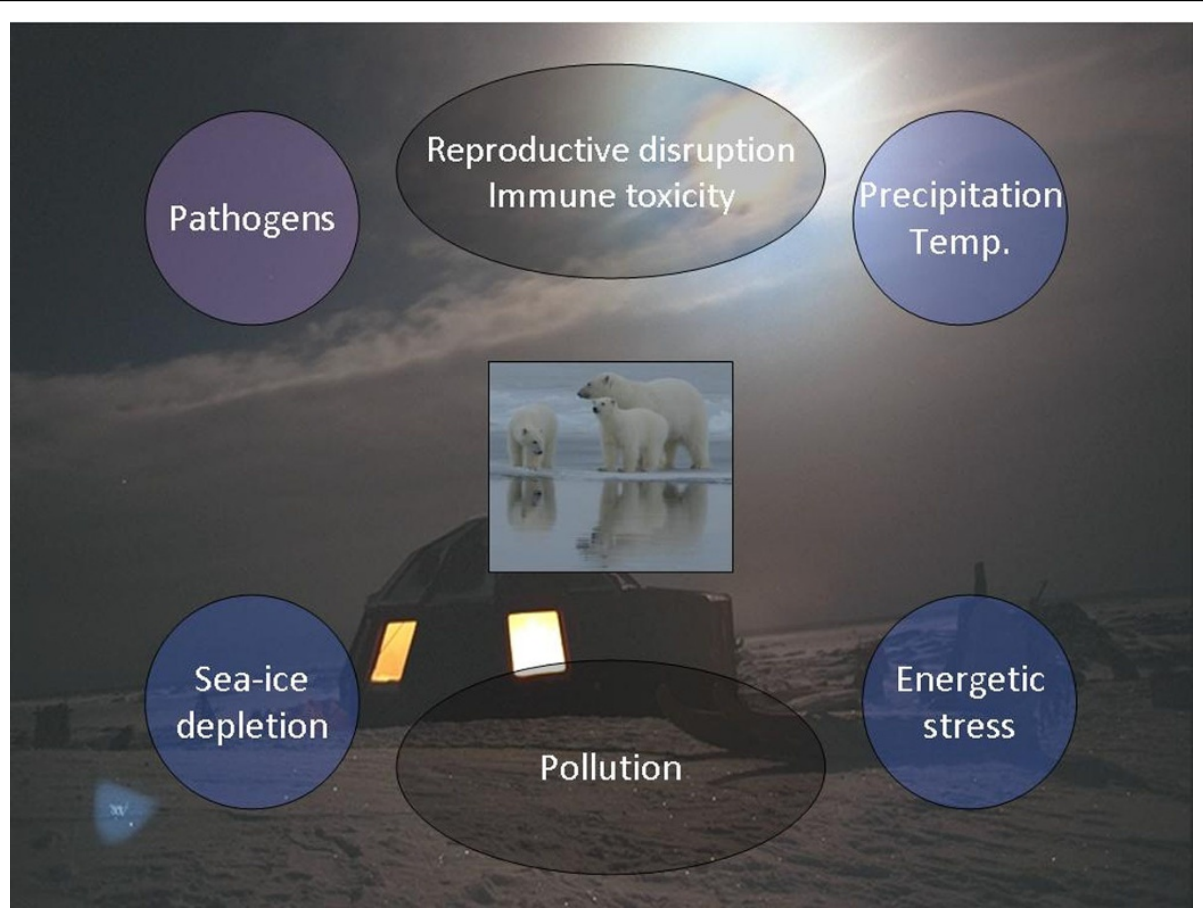

Figure 5 The multiple stressors in the Arctic that influences polar bear health. Oil and mineral activities, vessel shipment and subsistent hunt are not included. 
food access and negative energy balance may influence bear health via (sub)clinical impacts on immune functioning and reduced fecundity having an impact on populating size $[13,14,40-42]$. In addition to this global warming may also increase the infectious stress due to invasive micro pathogen and parasitic diseases $[13,14]$. The main challenge in the future is therefore to integrate the cumulative impact from these multiple stressors across temporal and spatial gradients by integrating empirical data and laboratory studies. The East Greenland polar bear seems an excellent biomonitoring organism for such.

\section{Conclusions}

East Greenland polar bears are among the most contaminated species on our globe in spite of their remote Arctic habitat. This sub-population inhabits Arctic biotopes being constantly under pressure from global warming and associated environmental changes. Anthropogenic environmental contaminants seem to be a co-factor in various organ-system lesions in East Greenland polar bears. This includes reduced bone density and sexual and reproductive organ size, thereby having potential impacts on individual health and population maintenance. On top of this, also global warming seems to affect polar bears via negative energy balances, which may have consequences for fecundity and immune resistance. The main challenge in the future is to integrate the cumulative impact from these multiple stressors across temporal and spatial gradients by integrating empirical data and laboratory studies.

\section{Acknowledgements}

The Lundbeck Foundation, Danish Cooperation for Environment in the Arctic (Dancea), The Commission for Scientific Research in Greenland (KVUG) and The Prince Albert II Foundation are acknowledged for financial support. Jonas Brønlund organized the sampling in East Greenland with invaluable help from the local hunters. No conflicts of interest were reported.
}

\begin{abstract}
Author details
${ }^{1}$ Department of Bioscience, Faculty of Science and Technology, Aarhus University, Frederiksborgvej 399, PO Box 358, DK-4000 Roskilde, Denmark. ${ }^{2}$ Ecotoxicology and Wildlife Health Division, Environment Canada, National Wildlife Research Centre, Carleton University, Ottawa, Ontario, K1A OH3, Canada. ${ }^{3}$ Aquatic Ecosystem Protection Research Division, Environment Canada, Burlington, Ontario, L7R 4A6, Canada. ${ }^{4}$ Department of Veterinary Disease Biology, Faculty of Life Sciences, University of Copenhagen, Bülowsvej 17, DK-1870 Frederiksberg, Denmark. ${ }^{5}$ Greenland Institute of Natural Resources, PO Box 570, DK-3900 Nuuk, Greenland, Denmark. ${ }^{6}$ University Hospital of Hvidovre, Kettegaards Allé 30, DK-2650 Hvidovre, Denmark. ${ }^{7}$ Department of Environmental Health Sciences, University of Michigan School of Public Health, Ann Arbor, MI, USA. ${ }^{8}$ Danish Agency for Science, Technology and Innovation Bredgade 40 DK-1260 Copenhagen K, Denmark.
\end{abstract}

Published: 24 February 2012

\section{References}

1. Born EW, Renzoni A, Dietz R: Total mercury in hair of polar bears (Ursus maritimus) from Greenland and Svalbard. Polar Res 1991, 9:113-120.
2. Dietz R, Rigét FF, Born EW: Geographical differences of zinc, cadmium, mercury and selenium in polar bears (Ursus maritimus) from Greenland. Sci Total Environ 2000, 245:25-47.

3. Dietz R, Rigét FF, Sonne C, Letcher RJ, Born EW, Muir DCG: Seasonal and temporal trends in polychlorinated biphenyls and organochlorine pesticides in East Greenland polar bears (Ursus maritimus), 1990-2001. Sci Total Environ 2004, 331:107-124.

4. Dietz R, Rigét FF, Born EW, Sonne C, Grandjean P, Kirkegaard M, Olsen MT, Asmund G, Renzoni A, Baagøe $H$, Andreasen C: Trends in mercury in hair of Greenlandic polar bears (Ursus maritimus) during 1892-2001. Environ Sci Technol 2006, 40:1120-1125.

5. Dietz R, Bossi R, Rigét FR, Sonne C, Born EW: Increasing perfluorinated acids in East Greenland polar bears (Ursus maritimus) - a new toxic threat to the Arctic bears. Environ Sci Technol 2008, 42:2701-2707.

6. Dietz R, Outridge PM, Hobson KA: Anthropogenic contributions to mercury levels in present-day Arctic Animals. Sci Total Environ 2009, 407:6120-6131.

7. Dietz R, Born EW, Rigét FF, Sonne C, Aubail A, Basu N: Temporal trends and future predictions of mercury concentrations in Northwest Greenland polar bear (Ursus maritimus) hair. Environ Sci Technol 2011, 45:1458-1465.

8. Bechshøft TØ, Wiig $\varnothing$, Sonne C, Rigét FF, Dietz R, Letcher RJ, Muir DCG: Temporal and spatial variation in metric asymmetry in skulls of polar bears (Ursus maritimus) from East Greenland and Svalbard. Annal Zool Fenn 2008, 45:15-31.

9. Bechshøft $T \varnothing$, Sonne C, Rigét FF, Wiig $\varnothing$, Dietz R: Differences in growth, size and sexual dimorphism in skulls of East Greenland and Svalbard polar bears (Ursus maritimus). Polar Biol 2008, 31:945-958.

10. Bechshøft $T \varnothing$, Rigét FF, Sonne C, Wiig $\varnothing$, Dietz R, Letcher RJ: Skull foramina asymmetry in East Greenland and Svalbard polar bears (Ursus maritimus) in relation to stressful environments. Annal Zool Fenn 2009, 46:181-192.

11. Sonne C, Rigét FF, Dietz R, Wiig $\varnothing$, Kirkegaard M, Born EW: Gross skull pathology in East Greenland and Svalbard polar bears (Ursus maritimus) during 1892 to 2002 in relation to organohalogen pollution. Sci Total Environ 2007, 372:554-561.

12. AMAP: Assessment 2010: Mercury in the Arctic. Arctic Monitoring and Assessment Programme: Oslo, Norway;.

13. Letcher RJ, Bustnes JO, Dietz R, Jenssen BM, Jørgensen EH, Sonne C Verreault J, Vijayan MM, Gabrielsen GW: Exposure and effects assessment of persistent organohalogen contaminants in Arctic wildlife and fish. Sci Total Environ 2010, 408:2995-3043.

14. Sonne C: Health effects from long-range transported contaminants in Arctic top predators: An integrated review based on studies of polar bears and relevant model species. Environ Int 2010, 36:461-491.

15. AMAP: AMAP Assessment 2009: Human Health in the Arctic. Arctic Monitoring and Assessment Programme (AMAP), Oslo, Norway; 2009, xiv+256, http://www.amap.no.

16. AMAP: AMAP Assessment Report: Arctic Pollution Issues. Arctic Monitoring and Assessment Programme (AMAP), Oslo, Norway; 1998, xii+859, http://www.amap.no.

17. AMAP: AMAP Assessment 2002: Persistent Organic Pollutants in the Arctic. Arctic Monitoring and Assessment Programme (AMAP), Oslo, Norway; 2004, xvi+310, http://www.amap.no.

18. Sonne C, Dietz R, Born EW, Rigét FF, Kirkegaard M, Hyldstrup L, Letcher RJ, Muir DCG: Is bone mineral composition disrupted by organochlorines in East Greenland polar bears (Ursus maritimus)? Environ Health Perspect 2004, 112:1711-1716

19. Lennox AR, Goodship AE: Polar bears (Ursus maritimus), the most evolutionary advanced hibernators, avoid significant bone loss during hibernation. Comp Biochem Physiol Part A 2008, 149:203-208.

20. Sonne C, Leifsson PS, Dietz R, Born EW, Letcher RJ, Hyldstrup L, Rigét FF, Kirkegaard M, Muir DCG: Xenoendocrine pollutants may reduce size of sexual organs in East Greenland polar bears (Ursus maritimus). Environ Sci Technol 2006, 40:5668-5674.

21. Ganong WF: Review of medical physiology. USA: Appleton and Lange; 22 2005, 928

22. Rosing-Asvid A: The influence of climate variability on polar bear (Ursus maritimus) and ringed seal (Pusa hispida) population dynamics. Can J Zool 2006, 84:357-364.

23. Sonne C, Leifsson PS, Dietz R, Born EW, Letcher RJ, Kirkegaard M, Muir DCG, Andersen LW, Rigét FF, Hyldstrup L: Enlarged clitoris in wild polar bears 
(Ursus maritimus) can be misdiagnosed as pseudohermaphroditism. Sc Total Environ 2005, 337:45-58.

24. Sonne C, Dietz R, Leifsson PS, Born EW, Kirkegaard M, Rigét FF, Letcher RJ, Muir DCG, Hyldstrup L: Do organohalogen contaminants contribute to liver histopathology in East Greenland polar bears (Ursus maritimus)? Environ Health Perspect 2005, 113:1569-1574.

25. Sonne C, Dietz R, Leifsson PS, Born EW, Kirkegaard M, Letcher RJ, Muir DCG, Rigét FF, Hyldstrup L: Are organohalogen contaminants a co-factor in the development of renal lesions in East Greenland polar bears (Ursus maritimus)? Environ Toxicol Chem 2006, 25:1551-1557.

26. Sonne C, Dietz R, Leifsson PS, Asmund G, Born EW, Kirkegaard M: Are liver and renal lesions in East Greenland Polar Bears (Ursus maritimus) associated with high mercury levels? Environ Health 2007, 6:11.

27. Sonne C, Bossi R, Dietz R, Leifsson PS, Rigét FF, Born EW: The potential correlation between perfluorinated acids and liver morphology in East Greenland polar bears (Ursus maritimus). Toxicol Environ Chem 2008, 90:275-283.

28. Sonne C, Leifsson PS, Iburg T, Dietz R, Born EW, Letcher RJ, Kirkegaard M: Thyroid gland lesions in organohalogen contaminated East Greenland polar bears (Ursus maritimus). Toxicol Environ Chem 2011, 93:789-805.

29. Basu N, Scheuhammer AM, Sonne C, Letcher RJ, Dietz R: Is dietary mercury of neurotoxicological concern to wild polar bears (Ursus maritimus)? Environ Toxicol Chem 2009, 28:133-140.

30. Basu N, Scheuhammer AM, Rouvinen-Watt K, Grochowina NM, Evans RD, O'Brien M, Chan HM: Decreased N-methyl-D-aspartic acid (NMDA) receptor levels are associated with mercury exposure in wild and captive mink. Neurotoxicology 2007, 28:587-593.

31. Scheuhammer AM, Basu N, Burgess N, Elliott JE, Campbell GD, Wayland M, Champoux L, Rodrigue J: Relationships among mercury, selenium, and neurochemical parameters in common loons (Gavia immer) and bald eagles (Haliaeetus leucocephalus). Ecotoxicology 2008, 17:93-101.

32. Pilsner JR, Lazarus AL, Nam D, Letcher RJ, Scheuhammer T, Sonne C, Dietz R, Basu N: Mercury-associated DNA hypomethylation in polar bear brains via the LUminometric Methylation Assay (LUMA): A sensitive method to study epigenetics in wildlife. Molecular Ecol 2010, 19:307-314.

33. Villanger GD, Munro Jenssen B, Fjeldberg RR, Letcher RJ, Muir DCG, Born EW, Kirkegaard M, Sonne C, Dietz R: Combined effects of mixtures of organohalogenated contaminants on thyroid hormones levels in polar bears. Environ Int 2011, 37:694-708.

34. Kirkegaard M, Sonne C, Leifsson PS, Dietz R, Born EW, Letcher RJ, Muir DCG: Histology of selected immunological organs in polar bear (Ursus maritimus) from East Greenland in relation to levels of organohalogens. Sci Total Environ 2005, 341:119-132.

35. Lie E, Larsen HJS, Larsen S, Johansen GM, Derocher AE, Lunn NJ, Norstrom RJ, Wiig $\varnothing$, Skaare JU: Does high organochlorine (OC) exposure impair the resistance to infection in polar bears (Ursus maritimus)? Part I: Effect of OCs on the humoral immunity. J Toxicol Environ Health A 2004, 67:555-582.

36. Lie E, Larsen HJS, Larsen $S$, Johansen GM, Derocher AE, Lunn NJ, Norstrom RJ, Wiig $\varnothing$, Skaare JU: Does high organochlorine (OC) exposure impair the resistance to infection in polar bears (Ursus maritimus)? Part II: Possible effects of OCs on mitogen- and antigen-induced lymphocyte proliferation. J Toxicol Environ Health A 2005, 68:457-484.

37. Sonne C, Dietz R, Larsen HJS, Loft KE, Kirkegaard M, Letcher RJ, Shahmiri S, Møller P: Impairment of cellular immunity in West Greenland sledge dogs (Canis familiaris) dietary exposed to polluted minke whale (Balaenoptera acutorostrata) blubber. Environ Sci Technol 2006, 40:2056-2062.

38. Sonne C, Fonfara S, Dietz R, Kirkegaard M, Letcher RJ, Shahmiri S, Andersen S, Møller P: Multiple cytokine and acute phase protein gene transcription in West Greenland sledge dogs (Canis familiaris) dietary exposed to organic environmental pollutants. Arch Environ Contam Toxicol 2007, 53:110-118.

39. Sonne C, Larsen HJS, Kirkegaard M, Letcher RJ, Dietz R: Trans-generational and neonatal immune suppression in West Greenland sledge dogs (Canis familiaris) exposed to organohalogenated environmental contaminants. Sci Total Environ 2010, 408:5801-5807.

40. Jenssen BM: Endocrine-disrupting chemicals and climate change: a worst-case combination for Arctic marine mammals and seabirds? Environ Health Perspect 2006, 114:76-80.
41. Molnár PK, Derocher AE, Thiemann GW, Lewis MA: Predicting survival, reproduction and abundance of polar bears under climate change. Biol Conserv 2010, 143:1612-1622.

42. Molnár PK, Derocher AE, Klanjscek T, Lewis MA: Predicting climate change impacts on polar bear litter size. Nature Comm 2011, 2:186, DOl: 10.1038/ ncomms1183.

\section{doi:10.1186/1751-0147-54-S1-S15}

Cite this article as: Sonne et al:: Two decades of biomonitoring polar bear health in Greenland: a review. Acta Veterinaria Scandinavica 201254 (Suppl 1):S15.

\section{Submit your next manuscript to BioMed Central and take full advantage of:}

- Convenient online submission

- Thorough peer review

- No space constraints or color figure charges

- Immediate publication on acceptance

- Inclusion in PubMed, CAS, Scopus and Google Scholar

- Research which is freely available for redistribution

Submit your manuscript at www.biomedcentral.com/submit
C Biomed Central 